ఠ

\title{
Methylnaltrexone for opioid-induced constipation: review and meta-analyses for objective plus subjective efficacy and safety outcomes
}

This article was published in the following Dove Press journal:

Therapeutics and Clinical Risk Management

II March 2016

Number of times this article has been viewed

\section{Waldemar Siemens \\ Gerhild Becker \\ Clinic for Palliative Care, Medical Center, University of Freiburg, Faculty of Medicine, University of Freiburg, Freiburg, Germany}

Introduction: Opioid-induced constipation (OIC) is a frequent adverse event that impairs patients' quality of life. This article evaluates the objective plus subjective efficacy and the safety of methylnaltrexone (MNTX) in OIC patients.

Methods: Randomized controlled trials from a recent systematic review were included. In addition, a PubMed search was conducted for January 2014 to December 21, 2015. We included randomized controlled trials with adult OIC patients, MNTX as study drug, and OIC as primary outcome. Results were categorized in three outcome types: objective outcome measures (eg, time to laxation), patient-reported outcomes (eg, straining), and global burden measures (eg, constipation distress). Dichotomous meta-analyses with risk ratios (RRs) and 95\% confidence intervals (CIs) were calculated using RevMan 5.3. Only comparisons between MNTX and placebo were made.

Results: We included seven studies with 1,860 patients. A meta-analysis revealed that patients under MNTX had considerably more rescue-free bowel movement within 4 hours after the first dose (RR 3.74, 95\% CI 2.87 to 4.86; five studies, $\mathrm{n}=938 ; r^{2}=0$ ). Results of the review indicated that patients under MNTX had a higher stool frequency and needed less time to laxation compared with placebo. Moreover, patients receiving MNTX tended to have better values in patient-reported outcomes and global burden measures. Meta-analyses on safety revealed that patients under MNTX experienced more abdominal pain (RR 2.38, 95\% CI 1.75 to 3.23; six studies, $n=1,412$; $r^{2}=60 \%$ ) but showed a nonsignificant tendency in nausea (RR $1.27,95 \%$ CI 0.90 to 1.78 ; six studies, $\mathrm{n}=1,412 ; I^{2}=12 \%$ ) and diarrhea (RR 1.45, 95\% CI 0.94 to 2.24; five studies, $\mathrm{n}=1,258$; $\left.P^{2}=45 \%\right)$. The incidence of MNTX-related serious adverse events was $0.2 \%(4 / 1,860)$.

Conclusion: MNTX has been shown to be effective and safe. Future randomized controlled trials should consequently incorporate objective outcome measures, patient-reported outcomes, and global burden measures, and research the efficacy of MNTX in other populations, for example, patients under opioids after surgical procedures.

Keywords: opioid-induced constipation, methylnaltrexone, patient-reported outcomes, review, meta-analysis

\section{Introduction}

Opioids are commonly prescribed to treat patients with cancer and noncancer pain. ${ }^{1,2}$ Opioid-induced constipation (OIC) is a frequent adverse event (AE) of opioid intake and its incidence may vary between $15 \%$ and $90 \% .^{3-5}$ It is one of various symptoms such as hard stools, incomplete evacuation, bloating, pain, nausea, and vomiting that belong to a symptom complex known as opioid-induced bowel dysfunction. ${ }^{6-8}$ Moreover, OIC considerably impedes patients' quality of life,,$^{3,49}$ and work productivity. This may result in additional costs to the health care system as well as society. ${ }^{9,10}$ 
Recent works have shown diverse pharmacological treatment opportunities for OIC patients, including methylnaltrexone (MNTX), naloxegol, naloxone, and lubiprostone..$^{6,11,12}$ However, a meta-analysis was only performed in the systematic review of Ford et $\mathrm{al}^{12}$ who used the individual author's definitions of "response" as outcome in their metaanalysis and, thus, comparability of the results is affected. In this work, we added relevant information by performing sound meta-analyses with homogeneous outcomes for each analysis. Moreover, we present efficacy of MNTX in the light of patient-reported outcomes (PROs) and global burden measures (GBMs) that are defined in the chapter Efficacy of MNTX.

Therefore, our aim is to evaluate the objective plus subjective efficacy and safety of MNTX in patients suffering from OIC.

\section{Pathophysiology and definition}

Opioids attach to opioid receptors (eg, $\mu$-opioid receptors) in the brain and the spinal cord, and relieve patients from pain in this way. ${ }^{13} \mu$-Opioid receptors also appear frequently in the enteric system and play an important role in mediating gastrointestinal effects, ${ }^{14}$ for example, in reducing bowel tone and contractility. In addition, opioids foster nonpropulsive contractions of the gut which may lead to an increased fluid absorption and harder stools. As a result of this, the sphincter tone increases and impairs rectal evacuation which leads to OIC. ${ }^{15,16}$

Defining or diagnosing OIC is challenging and only about a third of the clinical trials with interventions for OIC provide an explicit definition. ${ }^{17}$ In contrast to the Rome III Diagnostic Criteria for functional constipation, ${ }^{18} \mathrm{OIC}$ has a different pathophysiology and is correlated with the onset of opioid intake. Therefore, the following definition has been suggested:

We speak about OIC if the initiation of opioid therapy affects defecation patterns possibly resulting in a reduced spontaneous bowel movement (BM) frequency, the development or worsening of straining, a sense of incomplete evacuation or a harder stool consistency. ${ }^{17}$

Our definition overlaps in some principal points with the Rome III Diagnostic Criteria (eg, straining, hard stools, sensation of incomplete evacuation). However, our presented definition points to the temporal correlation with opioids and stays on a very individual level ("what individuals would consider as abnormal") in order to account for intersubjective variations.
Still, when choosing eligibility criteria for a study, pragmatic approaches are usually preferred. Some authors use $\mathrm{BM}$ frequency measures as inclusion criteria ${ }^{19-21}$ whereas others combine BM frequency measures with PROs. ${ }^{22-27}$ Moreover, in the field of OIC, most authors tend to define the response to therapy on the basis of BM frequency measures, for example, $\geq 3$ spontaneous BMs per week ${ }^{12}$ or BM within 4 hours after the first dose. ${ }^{6}$

\section{Methylnaltrexone}

If lifestyle modifications (eg, increase in dietary fiber or physical activity) and laxatives fail to improve OIC, opioid antagonists are usually recommended as the third step of OIC treatment because they have shown to be effective and address the pathomechanism of OIC. ${ }^{15,28} \mathrm{MNTX}$, naloxegol, naloxone, and alvimopan aim at antagonizing periphery $\mu$-receptors. These drugs have been studied in recent years..$^{6,7,12,29}$ Though MNTX was approved for OIC in 2008 by the US Food and Drug Administration and the European Medicines Agency, 13,30 still, some randomized controlled trials (RCTs) have been published in recent years. ${ }^{6,12}$ In order to consider the latest findings and evaluate objective plus subjective outcomes, we will concentrate on MNTX (or MNTX bromide) in this work. MNTX is a peripherally acting $\mu$-opioid receptor antagonist. It blocks $\mu$-opioid receptors in the gut and inhibits the action of opioids in this way. In contrast to naloxone, MNTX is less able to cross the blood-brain barrier. Therefore, MNTX does not affect opioid analgesia which is of high importance in cancer pain or palliative care patients. ${ }^{13}$

\section{Methods}

In this review, we refer to RCTs evaluating MNTX that were identified in a systematic review of our working group from 2015. ${ }^{6}$ In addition, PubMed was searched with the following strategy between January 2014 and December 21, 2015: “(methylnaltrexone OR MNTX) AND (opioid induced constipation OR OIC OR bowel dysfunction)." We included RCTs with adult OIC patients ( $<3$ BMs/week), MNTX as study drug, and with OIC as the primary outcome. Full texts, abstracts, and posters from conference proceedings were included as the eligibility criteria were applicable. We categorized the results in three outcome types: objective outcome measures (OOMs; eg, time to laxation), PROs (eg, straining), and GBMs (eg, constipation distress). Metaanalyses were performed if appropriate: Risk ratios (RRs) and $95 \%$ confidence intervals (CIs) were calculated using the Mantel-Haenszel method and the fixed-effect model. ${ }^{31}$ $I^{2}$ was used to describe heterogeneity in the meta-analyses. 
RevMan 5.3 (The Nordic Cochrane Centre, The Cochrane Collaboration, Copenhagen, Denmark) was used to conduct these dichotomous meta-analyses.

\section{Results}

In the previous systematic review, ${ }^{6}$ six studies were included. Another RCT was retrieved from our search in PubMed. Figure 1 displays an adapted study flow diagram according to the latest recommendations. ${ }^{32}$ In total, seven studies with 1,860 patients were included in the qualitative and up to six studies with 1,412 patients in the quantitative analyses. A responder analysis of two already included studies ${ }^{33}$ and a protocol of an upcoming $\mathrm{RCT}^{34}$ were also identified but subsequently excluded from further evaluation since they did not meet the eligibility criteria. In addition, one study ${ }^{35}$ was excluded after reading the full text because the study design was not appropriate (blinded placebo versus open-label MNTX group) and results were part of another RCT. ${ }^{36}$

MNTX was administered subcutaneously in all studies except in the study by Rauck et al. ${ }^{37}$ In four RCTs (50\%), participants were designated as patients with advanced illness (Table 1). The sample sizes ranged from $33^{26}$ to 804 patients. ${ }^{37}$ Five RCTs (71\%) included more than 132 patients. ${ }^{36-40}$ The dropout rates were mostly between $10 \%$ and $24 \%$.

\section{Efficacy of MNTX \\ Objective outcome measures}

OOMs are defined as "measures that could theoretically be collected by an investigator as well as by the patient (eg, bowel movements per week)." ${ }^{17}$ The primary endpoint of all included studies was an OOM ( $n=7 ; 100 \%)$. The majority $(n=4 ; 57 \%)$ chose rescue-free bowel movement (RFBM) within 4 hours after the first dose as the primary ${ }^{26,39}$ or coprimary ${ }^{36,40}$ outcome. RFBMs or rescue-free laxation is usually defined as a BM without prior use of any rescue medication or laxatives. "Prior" refers to an arbitrarily defined period of time that can differ between studies, for example, 4 hours $^{38}$ or 24 hours. ${ }^{26,36}$

The pooled RR for experiencing one RFBM within 4 hours after the first dose was considerably higher in patients under

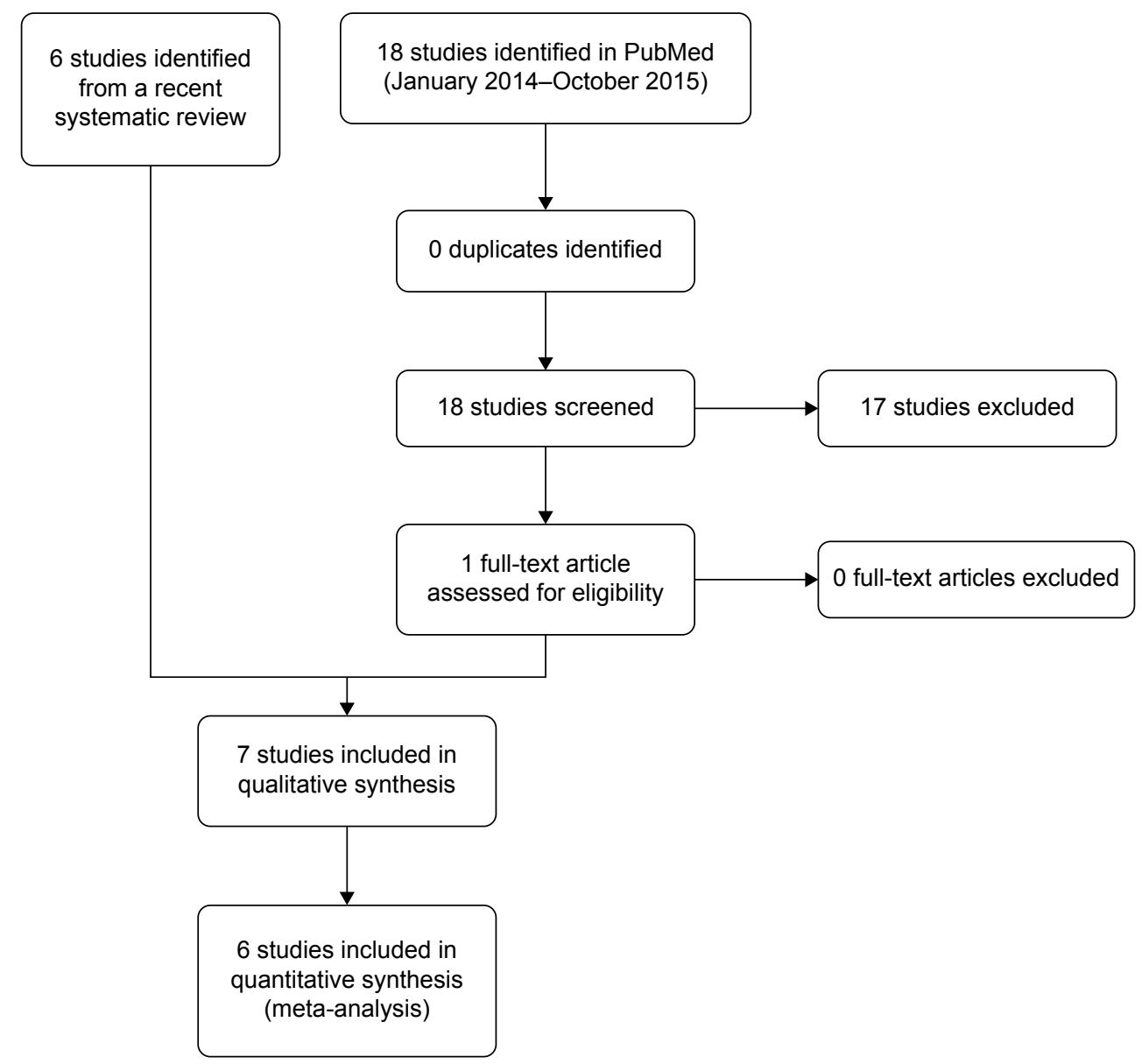

Figure I Methylnaltrexone randomized controlled trials for opioid-induced constipation treatment: study flow diagram. 
Table I Characteristics of included studies

\begin{tabular}{|c|c|c|c|c|}
\hline $\begin{array}{l}\text { Author (year), } \\
\text { existing source }\end{array}$ & $\begin{array}{l}\text { Drug, dosage, and treatment } \\
\text { period* }\end{array}$ & $\begin{array}{l}\text { OIC patient's } \\
\text { condition }\end{array}$ & $\begin{array}{l}\text { Sample size } \\
\text { (\% female) }\end{array}$ & Dropouts n (\%), comments \\
\hline $\begin{array}{l}\text { Bull et a }{ }^{38}(20 \mid 5) \text {, } \\
\text { full-text }\end{array}$ & $\begin{array}{l}\text { Sc MNTX; IG: } 38 \mathrm{~kg} \text { to }<62 \mathrm{~kg}: \\
8 \mathrm{mg} ; \geq 62 \mathrm{~kg}: 12 \mathrm{mg} \text {, qod; } 2 \text { weeks }\end{array}$ & $\begin{array}{l}\text { Advanced illness } \\
\text { (mostly cancer patients) }\end{array}$ & O: 230 (49\%) & $\begin{array}{l}\text { PBO: } 26(23 \%) \\
\text { IG: } 27(23 \%)\end{array}$ \\
\hline $\begin{array}{l}\text { Anissian et al }{ }^{42}(2012) \text {, } \\
\text { full-text }\end{array}$ & $\begin{array}{l}\text { Sc MNTX; IG: } 12 \text { mg, qd; } \\
4 \text { or } 7 \text { days }\end{array}$ & $\begin{array}{l}\text { Orthopedic surgical } \\
\text { procedure }\end{array}$ & O: 37 (67\%) & $\begin{array}{l}\text { PBO: } 3(20 \%) \\
\text { IG: } 3(17 \%)\end{array}$ \\
\hline $\begin{array}{l}\text { Rauck et al }{ }^{37,41} \text { (20I2), } \\
\text { abstract }\end{array}$ & $\begin{array}{l}\text { Oral MNTX; IGs: I50, 300, or } \\
450 \text { mg, qd; } 4 \text { weeks }\end{array}$ & Chronic noncancer pain & O: 804 (N/S) & $\begin{array}{l}\text { PBO: no dropouts reported } \\
\text { IGs: no dropouts reported }\end{array}$ \\
\hline $\begin{array}{l}\text { Michna et } a^{36}(201 \mathrm{I}) \\
\text { full-text }\end{array}$ & $\begin{array}{l}\text { Sc MNTX; IG I: I } 2 \text { mg, qd, IG2: } \\
\text { I2 mg, qod; } 4 \text { weeks }\end{array}$ & $\begin{array}{l}\text { Chronic nonmalignant } \\
\text { pain }\end{array}$ & O: 469 (59\%) & $\begin{array}{l}\text { PBO: I6 (I0\%), IG I: } 28 \text { (19\%), } \\
\text { IG2: } 28 \text { (19\%) }\end{array}$ \\
\hline $\begin{array}{l}\text { Slatkin et al }{ }^{39} \text { (2009), } \\
\text { full-text }\end{array}$ & $\begin{array}{l}\text { Sc MNTX; IG I: } 0.15 \mathrm{mg} / \mathrm{kg} \text {, IG2: } \\
0.3 \mathrm{mg} / \mathrm{kg} \text {; single injection; I day }\end{array}$ & $\begin{array}{l}\text { Advanced illness } \\
\text { (mostly cancer patients) }\end{array}$ & O: I54 (46\%) & $\begin{array}{l}\text { Dropouts: } 2 \text { (I\%); I noncompliant, } \\
\text { I died }\end{array}$ \\
\hline $\begin{array}{l}\text { Portenoy et } \mathrm{a}^{26}(2008) \text {, } \\
\text { full-text }\end{array}$ & $\begin{array}{l}\text { Sc MNTX; IG I: I mg, IG2: } 5 \text { mg, IG3: } \\
\text { I2.5 mg, IG4: } 20 \text { mg; qod; I week }\end{array}$ & $\begin{array}{l}\text { Advanced illness } \\
\text { (mostly cancer patients) }\end{array}$ & O: 33 (55\%) & $\begin{array}{l}\text { IGI: } 3 \text { (30\%), IG2: } 2 \text { (29\%), IG3: } 3 \\
\text { (30\%), IG4: } 3 \text { (50\%); Note: no PBO }\end{array}$ \\
\hline $\begin{array}{l}\text { Thomas et al }{ }^{40}(2008) \text {, } \\
\text { full-text }\end{array}$ & $\begin{array}{l}\text { Sc MNTX; IG: } 0.15 \mathrm{mg} / \mathrm{kg} \text {, qod; } \\
2 \text { weeks; note: } 0.30 \mathrm{mg} / \mathrm{kg} \text { when } \\
<3 \text { BMs/week after } 8 \text { days }\end{array}$ & $\begin{array}{l}\text { Advanced illness } \\
\text { (mostly cancer patients) }\end{array}$ & O: 133 (57\%) & $\begin{array}{l}\text { PBO: I7 (24\%), IG: I0 (I6\%); } \\
\text { Note: different doses in IG }\end{array}$ \\
\hline
\end{tabular}

Notes: *Refers to the blinded phase of the RCTs (not to the open-label phase or the follow-up). Adapted from Advances in pharmacotherapy for opioid-induced constipation - a systematic review, Siemens W, Gaertner J, Becker G, Expert Opin Pharmacother, 2015;16(4):5 I5-532, ${ }^{6}$ with the permission of the publisher (Taylor \& Francis Ltd, http://www. tandfonline.com).

Abbreviations: BM, bowel movement; IG, intervention group; MNTX, methylnaltrexone; n, number of patients; N/S, not specified; O, overall; OIC, opioid-induced constipation; PBO, placebo; qd, every day (Latin: quaque die); qod, every other day (Latin: quaque altera die); RCT, randomized controlled trial; Sc, subcutaneous.

MNTX (3.74, 95\% CI 2.87 to $4.86 ; P<0.00001)$ (Figure 2). The results were consistent across studies $\left(I^{2}=0\right)$.

The results for three common OOMs are presented in Table 2. A greater proportion of patients under MNTX experienced $\geq 3$ RFBMs per week compared with the placebo groups. ${ }^{36,37,40,41}$ The greatest difference was observed in the study by Thomas et $\mathrm{al}^{40}$ (MNTX: 68\%, placebo: $45 \%, P=0.009)$. The proportion of patients with an RFBM within 4 hours after the first dose and for all doses or $>1$ dose was significantly $(P<0.05)$ greater in patients under MNTX in all identified studies (Table 2). The median time to the first RFBM was significantly $(P<0.05)$ shorter for patients under MNTX with 0.8 hours as the smallest median. ${ }^{38,39}$

Moreover, Bull et $\mathrm{al}^{38}$ emphasized that no different responses between weight groups (Table 1) were found. Portenoy et $\mathrm{al}^{26}$ concluded for their dose-ranging study that no apparent dose-response $\geq 5 \mathrm{mg}$ could be observed which was supported by the results from Slatkin et al. ${ }^{39}$ Besides, oral MNTX may also be effective; for example, significant differences $(P \leq 0.02)$ in the $150 \mathrm{mg}(34 \%), 300 \mathrm{mg}(41 \%)$, and $450 \mathrm{mg}(42 \%)$ groups for an RFBM were observed within 24 hours compared with placebo $(23 \%) .{ }^{37}$ However, differences in RFBM frequency measures and RFBM within 4 hours for all doses were only statistically significant for the 300 and $450 \mathrm{mg}$ groups but not for the $150 \mathrm{mg}$ group (Table 2). ${ }^{41}$ The authors concluded that a linear doseresponse was existent.

\section{Patient-reported outcomes}

PROs are defined as "reports coming directly from patients about how they feel or function in relation to a health condition and its therapy without interpretation by health care professionals or anyone else." ${ }^{31}$ In this review, five of seven (71\%) included studies reported PROs (Table 3). Only one study of the three latest studies (2012-2015)

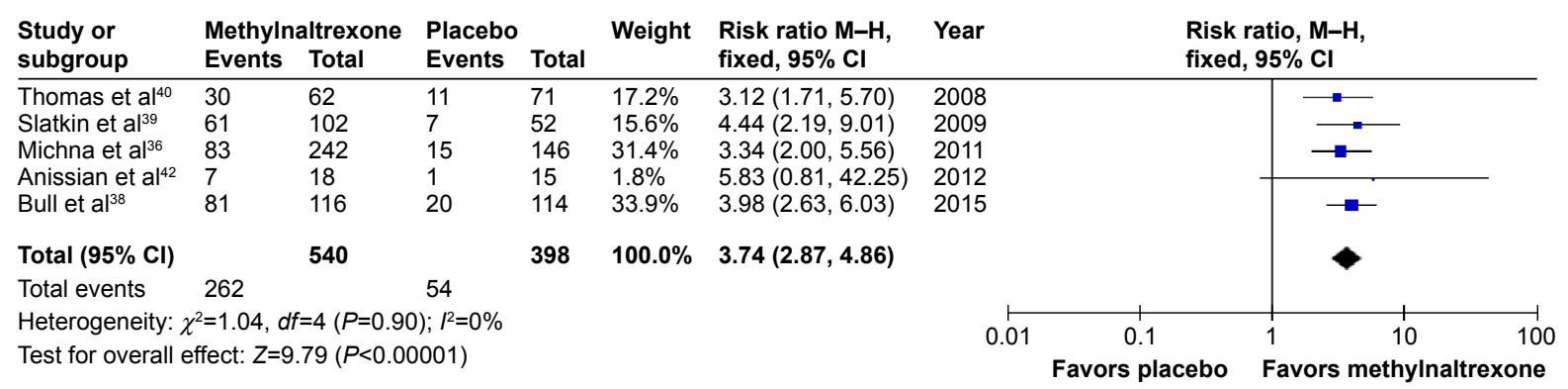

Figure 2 Methylnaltrexone versus placebo: rescue-free bowel movement within 4 hours after the first dose. 
Table 2 Objective outcome measures assessing OIC

\begin{tabular}{|c|c|c|}
\hline Author (year) & Category & Results \\
\hline Bull et $\mathrm{al}^{38}$ & BM frequency & - \\
\hline \multirow[t]{4}{*}{$(2015)$} & BM within 4 hours & RFBM: after $\geq 2$ of the first 4 doses: MNTX: $62.9 \%$ vs PBO: $9.6 \%(P<0.000 I)$ \\
\hline & & RFBM after the first dose: MNTX: $69.8 \%$ vs PBO: $17.5 \%(P<0.000 I)$ \\
\hline & & RFBM after $\geq 4$ of the maximum 7 doses: MNTX $62.2 \%$ vs PBO: $4.9 \%(P<0.000 \mathrm{I})$ \\
\hline & Time to first BM & RFBM after first dose: median time for MNTX: 0.8 hours vs PBO: 23.6 hours $(P<0.000 I)$ \\
\hline Anissian et $\mathrm{al}^{42}$ & BM frequency & - \\
\hline \multirow[t]{3}{*}{ (20I2) } & BM within 4 hours & First dose: laxation IG > PBO, 4 hours: $38.9 \%$ vs $6.7 \%, P=0.046$ \\
\hline & & Note: laxation within 2 hours: $33.3 \%$ vs $0 \%, P=0.02$ I \\
\hline & Time to first BM & IG $<$ PBO, median time to laxation: 15.8 vs 50.9 hours, $P=0.0197$ \\
\hline \multirow[t]{7}{*}{$\begin{array}{l}\text { Rauck et al }{ }^{37,41} \\
(2012)\end{array}$} & BM frequency & $\begin{array}{l}\geq 3 \text { RFBMs/week with an increase of } \geq \text { I RFBM/week over baseline for } \geq 3 \text { of first } 4 \text { weeks: } 150 \mathrm{mg} \text { : } \\
41.3 \% \text { (ns), } 300 \mathrm{mg}: 47.8 \%(P=0.03), 450 \mathrm{mg}: 50.5 \%(P=0.008) ; P \text {-values based on comparison with }\end{array}$ \\
\hline & & PBO: $36.8 \%$ \\
\hline & & RFBM/week mean change from baseline: I $50 \mathrm{mg}:$ I.88 (ns), $300 \mathrm{mg}: 2.39$ ( $P=0.009), 450 \mathrm{mg}$ : \\
\hline & & $2.40(P=0.009) ; P$-values based on comparison with PBO: I.7| \\
\hline & BM within 4 hours & All doses, RFBM: I50 mg: $21.1 \%(P=0.31), 300 \mathrm{mg}: 24.6 \%(P=0.004), 450 \mathrm{mg}: 27.4 \%(P<0.000 \mathrm{I})$; \\
\hline & & $P$-values based on comparison with PBO: $18.1 \%$ \\
\hline & Time to first BM & - \\
\hline Michna et $\mathrm{al}^{36}$ & BM frequency & $\geq 3$ RFBMs/week: IGI: $58.7 \%$, IG2: 45.3\%, PBO: $38.3 \%$ \\
\hline \multirow[t]{4}{*}{$(2011)$} & & Baseline RFBM I: mean change: IGI: 3.I, IG2: 2.2, PBO: I.5, both IGs $P<0.01$ vs PBO \\
\hline & BM within 4 hours & First dose (RFBM): IGI: 33.3\%, IG2: 35.1\%, PBO: 9.9\%; both IGs $P<0.00$ I vs PBO \\
\hline & & All doses (RFBM): IGI: $28.9 \%$, IG2: 30.2\%, PBO: 9.3\%; both IGs $P<0.00$ I vs PBO \\
\hline & Time to first BM & IGI and IG2 shorter compared with $\mathrm{PBO}, P<0.00 \mathrm{I}$ \\
\hline Slatkin et $\mathrm{a}^{39}$ & BM frequency & - \\
\hline \multirow[t]{4}{*}{ (2009) } & BM within 4 hours & Single dose (RFBM): MNTX $0.15 \mathrm{mg} / \mathrm{kg}: 61.7 \%$ (95\% Cl, $47.8 \%$ to $75.6 \%)$ \\
\hline & & MNTX $0.3 \mathrm{mg} / \mathrm{kg}: 58.2 \%(95 \% \mathrm{Cl}, 45.1 \%$ to $71.2 \%)$ \\
\hline & & PBO: $13.5 \%(95 \% \mathrm{Cl}, 4.2 \%$ to $22.7 \%) ;$ IGs vs $\mathrm{PBO} P<0.000 \mathrm{I}$ \\
\hline & Time to first BM & Median time to RFBM: IGI: I.I hours, IG2: 0.8 hours, PBO $>24$ hours, both IGs vs PBO $P<0.000$ I \\
\hline *Portenoy & BM frequency & - \\
\hline \multirow[t]{2}{*}{ et $\mathrm{al}^{26}(2008)$} & BM within 4 hours & $\begin{array}{l}\text { First dose: MNTX I mg: I/I0 ( } 10 \%) \text {; MNTX } 5 \text { mg: } 3 / 7 \text { (43\%); MNTX } 12.5 \text { mg: 6/I0 (60\%), MNTX } \\
20 \text { mg: } 2 / 6 \text { (33\%); MNTX } \geq 5 \text { mg: I I/23 (48\%) }\end{array}$ \\
\hline & Time to first BM & $\begin{array}{l}\text { Median time to laxation was }>48 \text { hours for the } 1 \mathrm{mg} \text { dose group and } \mathrm{I} .72,0.48 \text {, and } 6.75 \text { hours in } \\
\text { the } 5,12.5 \text {, and } 20 \mathrm{mg} \text { dose groups }\end{array}$ \\
\hline Thomas et $\mathrm{al}^{40}$ & BM frequency & $\geq 3$ RFBMs/week: MNTX: 68\%, PBO: $45 \%, P=0.009$ \\
\hline \multirow[t]{4}{*}{ (2008) } & BM within 4 hours & First dose: MNTX: $48 \%, \mathrm{PBO}: 15 \%, P<0.00 \mathrm{I}$ \\
\hline & & After one or more doses: MNTX: $79 \%$, PBO: $46 \%$ \\
\hline & & After $\geq 2$ of the first 4 doses: MNTX: $52 \%$, PBO: $8 \%, P<0.00$ I \\
\hline & Time to first BM & First dose, median: MNTX: 6.3 hours, PBO: $>48$ hours, $P<0.001$ \\
\hline
\end{tabular}

Notes: *Dose-ranging study; no placebo. Adapted from Advances in pharmacotherapy for opioid-induced constipation-a systematic review, Siemens W, Gaertner J, Becker G. Expert Opin Pharmacother, 2015; 16(4):515-532, ${ }^{6}$ with the permission of the publisher (Taylor \& Francis Ltd, http://www.tandfonline.com).

Abbreviations: BM, bowel movement; IG, intervention group; MNTX, methylnaltrexone; ns, not (statistically) significant; OIC, opioid-induced constipation; PBO, placebo; RFBM, rescue-free bowel movement; $\mathrm{Cl}$, confidence interval.

captured PROs. ${ }^{42}$ The PROs in these five studies were very heterogeneous. ${ }^{26,36,39,40,42}$ In a study from Anissian et al, ${ }^{42}$ satisfaction with treatment was $23 \%$ (after 4 hours) and $30 \%$ (after 7 days) higher in the MNTX group compared with placebo but no trend could be observed in a dose-ranging study by Portenoy et al. ${ }^{26}$ The Global Clinical Impression of Change identified considerably more MNTX patients than placebo patients under the category "improved" (slightly better, somewhat better, much better) (Table 3). ${ }^{39,40}$ However, no dose-response relationship could be identified for the Global Clinical Impression of Change, ${ }^{39}$ straining, and sensation of complete evacuation. ${ }^{36}$ In addition, it can be criticized that difficulty in passing stool and patient satisfaction with study medication ${ }^{26,40}$ were presented without any quantitative information.

\section{Patient-reported GBMs}

GBMs were defined as "PROMs that directly quantify the patients' distress and the impact of OIC on their daily activities or quality of life" in a previous paper. ${ }^{17}$ Differentiating between PROMs and GBMs is highly important since a PROM (eg, straining) does not automatically imply that the patient feels distressed or that his/her quality of life is affected. 
Table 3 Patient-reported outcomes assessing OIC

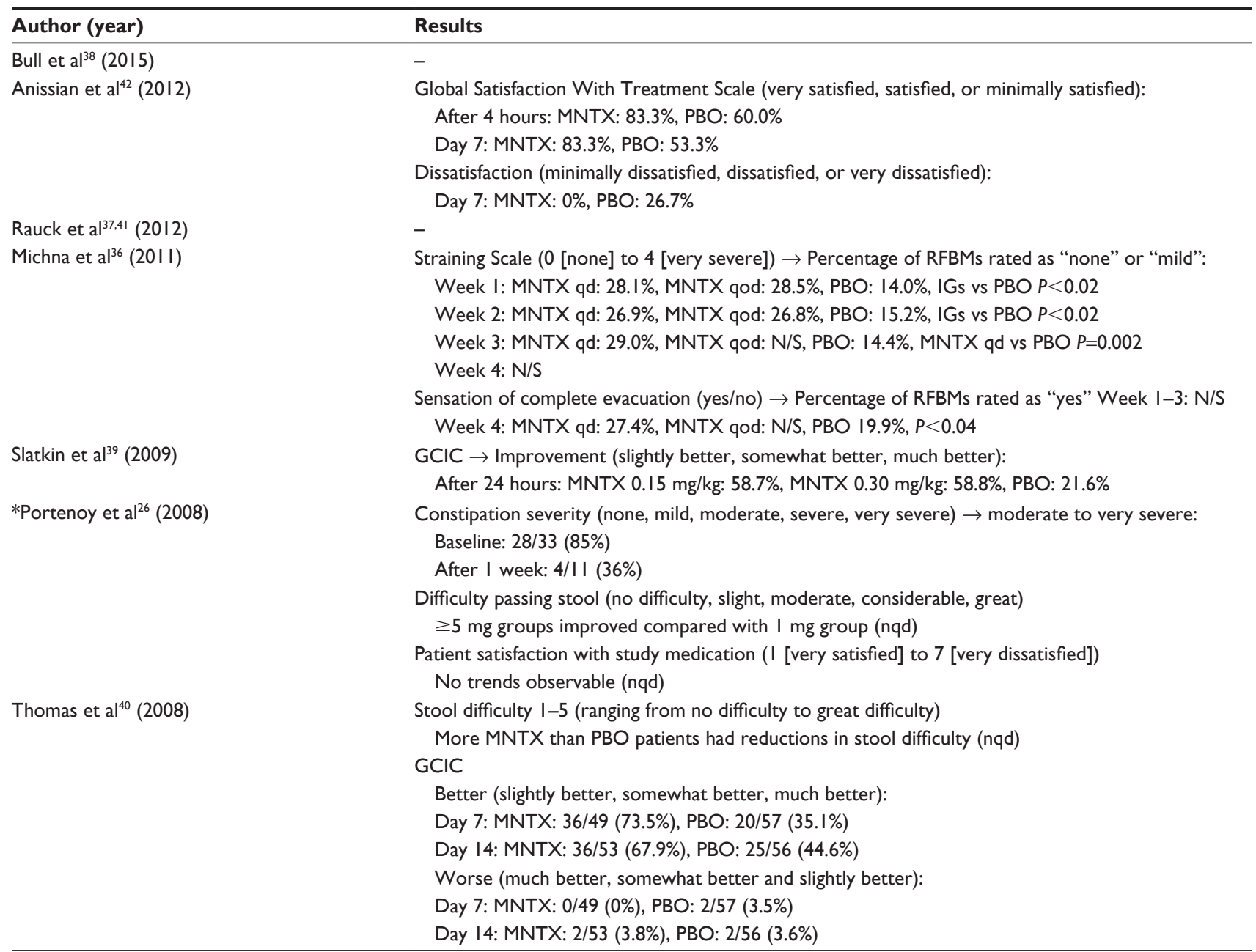

Notes: *Cave: dose-ranging study; no placebo.

Abbreviations: GCIC, Global Clinical Impression of Change; IG, intervention group; MNTX, methylnaltrexone (group); N/S, not specified; nqd, no quantitative data provided; OIC, opioid-induced constipation; PBO, placebo; qd, every day (Latin: quaque die); qod, every other day (Latin: quaque altera die); RFBM, rescue-free bowel movement.

Table 4 Global burden measures assessing OIC

\begin{tabular}{|c|c|}
\hline Author (year) & Results \\
\hline Bull et a ${ }^{38}(2015)$ & - \\
\hline Anissian et $\mathrm{al}^{42}(2012)$ & - \\
\hline Rauck et $\mathrm{al}^{37,41}(2012)$ & - \\
\hline \multirow[t]{4}{*}{ Michna et $\mathrm{al}^{36}(20 \mathrm{II})$} & PAC-QOL (0-4; smaller values indicate a better status) \\
\hline & Improvement for week 4: \\
\hline & MNTX qd: -0.74 (33\%), PBO: -0.39 (I8\%), P<0.00I; \\
\hline & MNTX qod: -0.59 (27\%), $P=0.014$ from baseline but ns compared with PBO \\
\hline \multirow[t]{4}{*}{ Slatkin et $\mathrm{al}^{39}$ (2009) } & Constipation distress (I [none]; 2 [a little bit]; 3 [somewhat]; 4 [quite a bit]; \\
\hline & 5 [very much]) \\
\hline & Improvement (change by at least one category toward none): \\
\hline & After 4 hours: MNTX 0.15 mg/kg: 64.4\%, MNTX 0.30 mg/kg 63.5\%, PBO: 34.0\% \\
\hline \multirow[t]{3}{*}{ *Portenoy et $\mathrm{al}^{26}(2008)$} & Constipation distress (none, a little bit, somewhat, quite a bit, or very much) \\
\hline & Baseline: $28 / 33(85 \%)$ with somewhat, quite a bit, or very much distress \\
\hline & After I week: 4/II (36\%) with somewhat, quite a bit, or very much distress \\
\hline \multirow[t]{2}{*}{ Thomas et al ${ }^{40}(2008)$} & Constipation-related distress (rated on a scale from "none" to "very much") \\
\hline & More MNTX than PBO patients had reductions in distress (nqd) \\
\hline
\end{tabular}

Notes: *Cave: dose-ranging study; no placebo.

Abbreviations: MNTX, methylnaltrexone; nqd, no quantitative data provided; ns, not statistically significant; OIC, opioid-induced constipation; PAC-QOL, Patient Assessment of Constipation-Quality of Life; PBO, placebo; qd, every day (Latin: quaque die); qod, every other day (Latin: quaque altera die). 


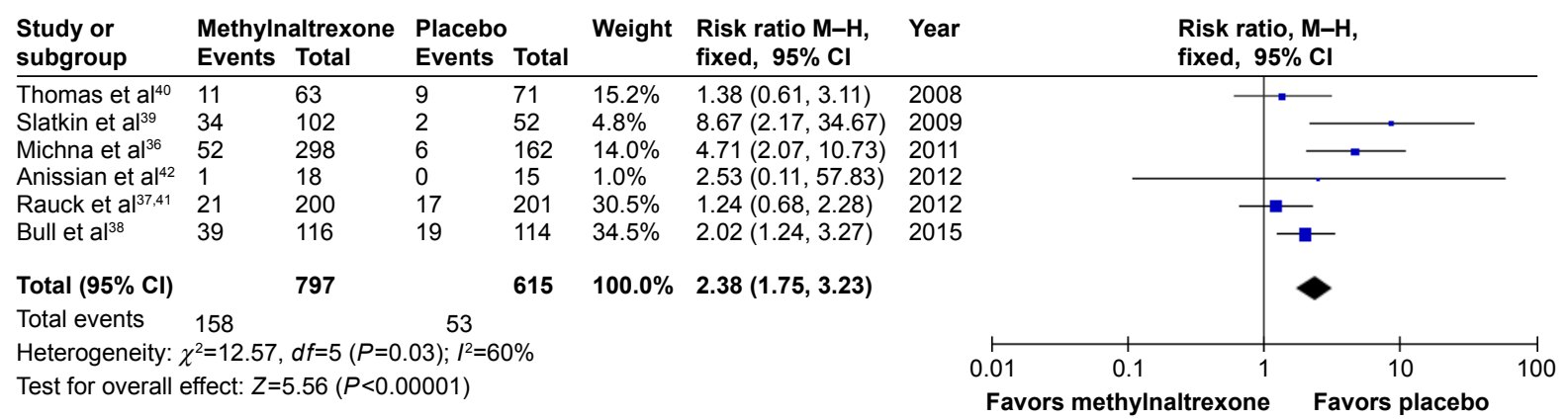

Figure 3 Methylnaltrexone versus placebo: abdominal pain.

The latest three studies (43\%) did not include a $\mathrm{GBM}^{37,38,42}$ in contrast to the studies conducted between 2008 and 2011 (Table 4). ${ }^{26,36,39,40}$ Constipation distress was assessed in three studies and the results indicated an improvement in the MNTX groups. ${ }^{26,39,40}$ However, the results for constipation distress were presented in a shortened way ${ }^{26,40}$ and quantitative data were not provided in one study. ${ }^{40}$

Moreover, MNTX groups had a larger improvement in the Patient Assessment of Constipation-Quality of Life questionnaire. ${ }^{36}$ Patients in the MNTX groups (daily and every other day) and in the placebo group improved by $33 \%$, $27 \%$, and $18 \%$, respectively. ${ }^{36}$ In accordance with the Global Clinical Impression of Change results (Table 3), no doseresponse relationship could be identified for constipation distress or the Patient Assessment of Constipation-Quality of Life as the differences between the MNTX groups were not statistically or clinically relevant (Table 4). ${ }^{36,39}$

\section{Safety of MNTX}

The most frequent AEs during the treatment with peripherally acting $\mu$-opioid receptor antagonists are usually abdominal pain, nausea, and diarrhea ${ }^{6}$ For abdominal pain, the meta-analysis in this review included six studies with a total of 1,412 patients. It revealed that patients under MNTX have a considerably higher risk to experience abdominal pain (RR 2.38, 95\% CI 1.75 to 3.23) (Figure 3). A subgroup analysis showed that this effect was consistent for cancer and noncancer patients (Figure 4). Interestingly, the effect for noncancer patients disappeared (RR 2.35, 95\% CI 0.75 to 7.36) when using the random-effects model for sensitivity analysis but still remained for cancer patients (RR 2.39, 95\% CI 1.07 to 5.34) (Figure 5). In addition, patients treated with MNTX showed only a tendency towards statistical significance concerning nausea and diarrhea when compared with placebo. In a meta-analysis with six studies

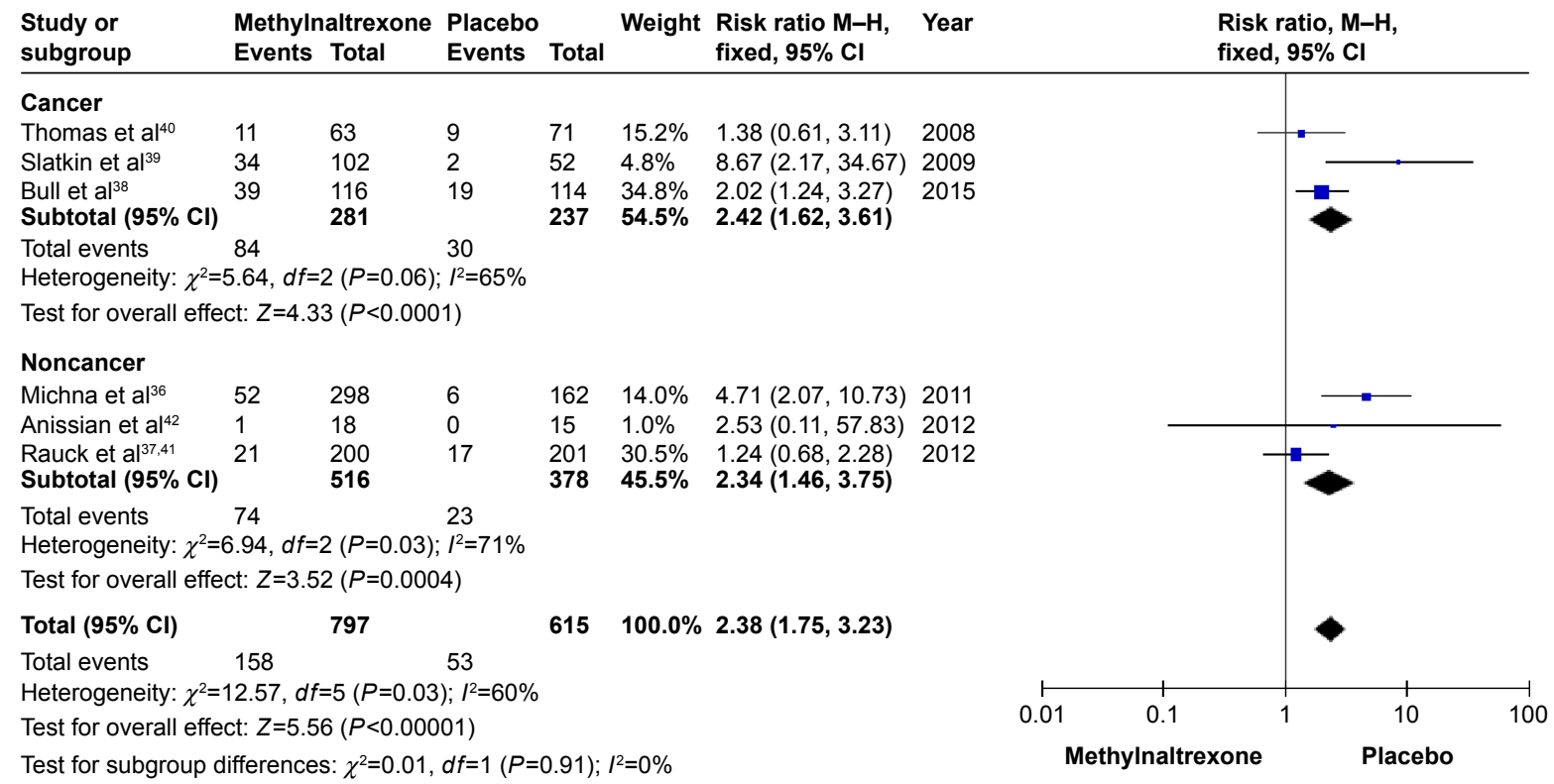

Figure 4 Subgroup analysis for cancer vs noncancer patients: abdominal pain. 


\begin{tabular}{|c|c|c|c|c|c|c|}
\hline $\begin{array}{l}\text { Study or } \\
\text { subgroup }\end{array}$ & $\begin{array}{l}\text { Methyln } \\
\text { Events }\end{array}$ & $\begin{array}{l}\text { altrexone } \\
\text { Total }\end{array}$ & $\begin{array}{l}\text { Placebo } \\
\text { Events }\end{array}$ & Total & Weight & $\begin{array}{l}\text { Risk ratio } \mathrm{M}-\mathrm{H} \text {, } \\
\text { random, } 95 \% \mathrm{Cl}\end{array}$ \\
\hline \multicolumn{7}{|l|}{ Cancer } \\
\hline $\begin{array}{l}\text { Thomas et } \mathrm{al}^{40} \\
\text { Slatkin et } \mathrm{al}^{39} \\
\text { Bull et al }{ }^{38} \\
\text { Subtotal }(95 \% \mathrm{CI}) \\
\text { Total events } \\
\text { Heterogeneity: } \tau^{2}=0 \text {. }\end{array}$ & $\begin{array}{l}84 \\
32 ; \chi^{2}=5.6\end{array}$ & $\begin{array}{l}63 \\
102 \\
116 \\
\mathbf{2 8 1} \\
4, d f=2(P\end{array}$ & 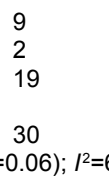 & $\begin{array}{l}71 \\
52 \\
114 \\
237 \\
65 \%\end{array}$ & $\begin{array}{l}19.0 \% \\
10.7 \% \\
25.6 \% \\
\mathbf{5 5 . 3} \%\end{array}$ & $\begin{array}{l}1.38(0.61,3.11) \\
8.67(2.17,34.67) \\
2.02(1.24,3.27) \\
\mathbf{2 . 3 9}(\mathbf{1 . 0 7}, \mathbf{5 . 3 4})\end{array}$ \\
\hline \multicolumn{7}{|c|}{ Test for overall effect: $Z=2.12(P=0.03)$} \\
\hline \multicolumn{7}{|l|}{ Noncancer } \\
\hline $\begin{array}{l}\text { Michna et } \mathrm{al}^{36} \\
\text { Anissian et } \mathrm{al}^{42} \\
\text { Rauck et } \mathrm{al}^{37,41} \\
\text { Subtotal }(\mathbf{9 5 \%} \mathrm{CI})\end{array}$ & $\begin{array}{l}52 \\
1 \\
21\end{array}$ & $\begin{array}{l}298 \\
18 \\
200 \\
\mathbf{5 1 6}\end{array}$ & $\begin{array}{l}6 \\
0 \\
17\end{array}$ & $\begin{array}{l}162 \\
15 \\
201 \\
\mathbf{3 7 8}\end{array}$ & $\begin{array}{l}18.8 \% \\
2.9 \% \\
23.0 \% \\
44.7 \%\end{array}$ & $\begin{array}{l}4.71(2.07,10.73) \\
2.53(0.11,57.83) \\
1.24(0.68,2.28) \\
\mathbf{2 . 3 5}(\mathbf{0 . 7 5}, 7.36)\end{array}$ \\
\hline \multicolumn{7}{|c|}{ Heterogeneity: $\tau^{2}=0.62 ; \chi^{2}=6.94, d f=2(P=0.03) ; I^{2}=71 \%$} \\
\hline \multicolumn{7}{|c|}{ Test for overall effect: $Z=1.47(P=0.14)$} \\
\hline Total $(95 \% \mathrm{Cl})$ & & 797 & & 615 & $100.0 \%$ & $2.32(1.33,4.05)$ \\
\hline \multicolumn{7}{|c|}{ Heterogeneity: $\tau^{2}=0.26 ; \chi^{2}=12.57, d f=5(P=0.03) ; I^{2}=60 \%$} \\
\hline $\begin{array}{l}\text { Test for overall effec } \\
\text { Test for subgroup di }\end{array}$ & $\begin{array}{l}\text { t: } Z=2.95 \\
\text { ferences: }\end{array}$ & $(P=0.003)$ & 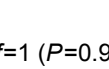 & & & \\
\hline
\end{tabular}

Figure 5 Random-effects model: subgroup analysis for cancer vs noncancer patients: abdominal pain.

and 1,412 patients, the risk for experiencing nausea was not significantly higher in patients under MNTX (RR 1.27, $95 \%$ CI 0.90 to $1.78 ; P=0.34$ ) (Figure 6). The meta-analysis for the risk of experiencing diarrhea included five studies with 1,258 patients (Figure 7). Though there was a trend in favor of placebo (RR 1.45, 95\% CI 0.94 to 2.24 ), the metaanalysis remained statistically not significant $(P=0.12)$. The study by Bull et a $\mathrm{l}^{38}$ questioned the results of the previous studies by showing a contrary effect (RR $0.59,95 \%$ CI 0.27 to 1.29), that is, it favors patients under MNTX which leads to an $I^{2}$ of $45 \%$. In contrast to previous meta-analyses, ${ }^{6}$ the studies by Bull et $\mathrm{al}^{38}$ and Rauck et $\mathrm{a}^{41}$ were included in the meta-analyses of this review. The consideration of both studies contributed to smaller RRs for abdominal pain ( $R R-1.62$ ), nausea ( $R R-0.26$ ), and diarrhea ( $R R-0.48$ ) compared with the recent meta-analyses by Siemens et $\mathrm{al}^{6}$ and led to a slightly better safety profile than observed in naloxegol for these AEs.
None of the studies reported increased pain or opioid withdrawal symptoms in patients treated with MNTX. ${ }^{26,36-39,42}$

In all but one study, the route of administration was subcutaneous. Rauck et $\mathrm{al}^{41}$ administered MNTX orally. They concluded that the incidence of AEs was low and that no notable differences in laboratory results or electrocardiogram findings were observed.

The authors of four studies (57\%) judged that the observed serious adverse events (SAEs) were not related to MNTX. In total, four MNTX-related SAEs in 1,860 patients $(0.2 \%)$ were observed. A 50-year-old white female developed extrasystoles in the first day of the double-blind phase that were considered to be related to MNTX. ${ }^{36}$ Slatkin et al ${ }^{39}$ reported severe diarrhea, dehydration, and cardiovascular collapse in one patient. Flushing occurred in one patient and delirium in another. All three SAEs were considered to be related to the study drug.

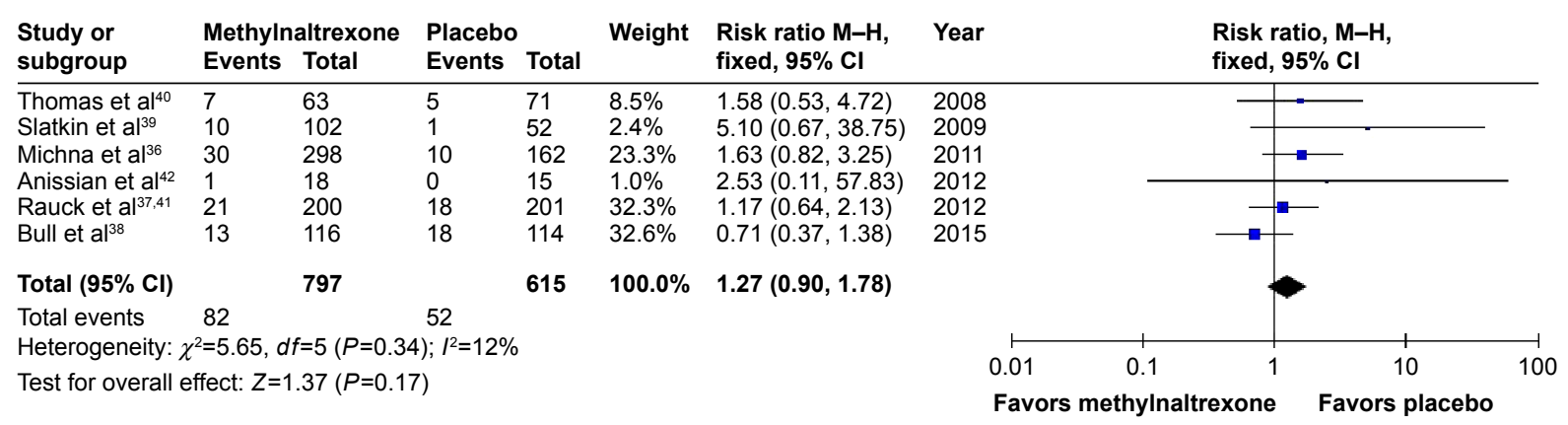

Figure 6 Methylnaltrexone versus placebo: nausea. 


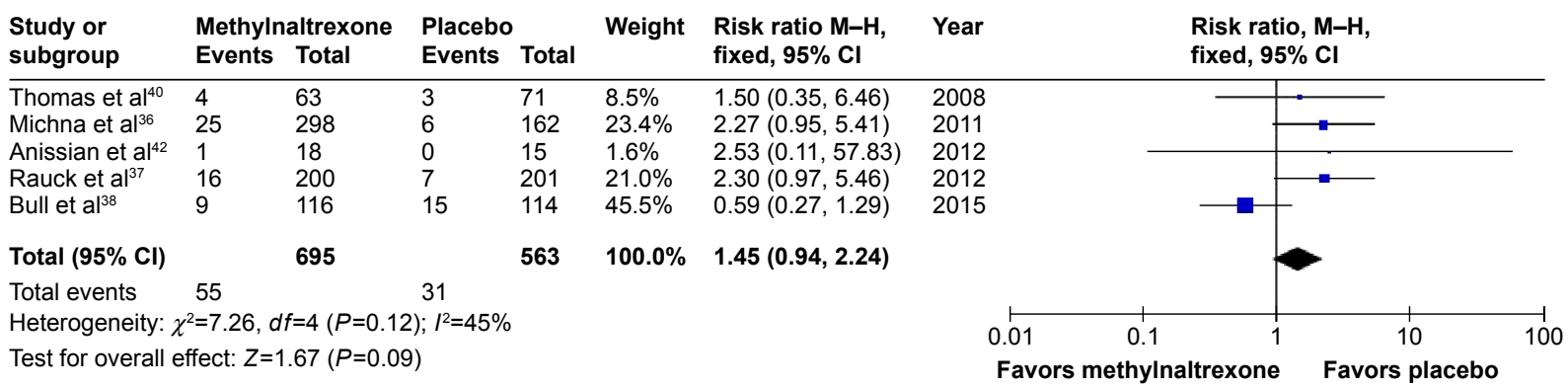

Figure 7 Methylnaltrexone versus placebo: diarrhea.

Moreover, no events of gastrointestinal perforation were reported in the included studies but seven cases with gastrointestinal perforation were identified in the Adverse Event Reporting System. ${ }^{43}$ A possible mechanism for gastrointestinal perforation may be the strong prokinetic effect of MNTX combined with a compromised integrity of the patients' gastrointestinal tract. ${ }^{43}$

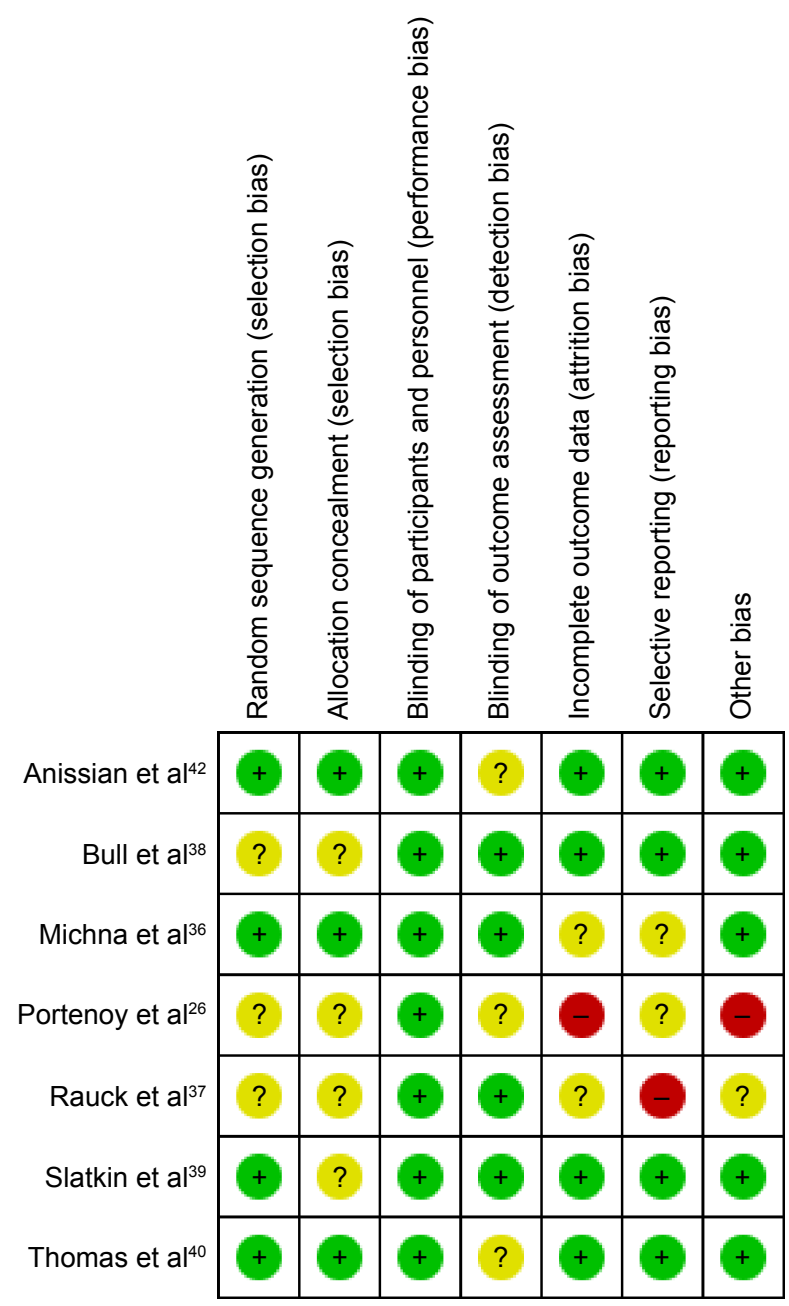

Figure 8 Risk of bias summary.

Note: + refers to low risk of bias; ? refers to unclear risk of bias; - refers to high risk of bias.

\section{Risk of bias}

Figure 8 shows the authors' judgment about each risk of bias item for the seven included RCTs. All studies had a low risk for performance bias since they were double-blind. The random sequence generation and the allocation concealment were not described in three (43\%) and four $(57 \%)$ of the included studies, respectively. One study ${ }^{26}$ was not included in the meta-analyses because of relevant baseline differences (other bias) and a high attrition bias (dropout rate: $29 \%-50 \%$ ) that could have affected the effect estimate. For another study, ${ }^{37}$ only the abstract was available which resulted in an unclear risk of bias for four items. Moreover, there was a high reporting bias because of differences between publication and protocol (NCT01186770) concerning the primary outcome.

All in all, the risk of bias can be considered as acceptable. However, it should be noted that all studies were sponsored by pharmaceutical companies: five by Valeant Pharmaceuticals International, ${ }^{36,38-40,42}$ one by Progenics Pharmaceuticals, ${ }^{26}$ and one by Salix Pharmaceuticals. ${ }^{37}$

\section{Alternatives}

Various reviews investigating drugs for OIC treatment have been identified. ${ }^{6,11,12,28,44,45}$ They support that MNTX, naloxegol, naloxone, alvimopan, lubiprostone, CB-5945, and prucalopride are effective pharmacological interventions against OIC. However, most works focus on OOMs whereas this review contributes to the awareness of PROs and GBMs for the efficacy evaluation of OIC drugs.

Choosing a drug to target OIC depends on many factors. Still, some authors provide a reasonable concept and suggest that laxatives should be used as the first step in pharmacological treatment. If these are not effective, peripherally acting $\mu$-opioid receptor antagonists may be prescribed in addition. ${ }^{15,28}$

\section{Limitations}

This review refers to studies identified in the systematic review from Siemens et $\mathrm{al}^{6}$ and from an updated search in 
PubMed (January 2014 and December 2015). The short but precise search strategy was presented in the "Methods" section. However, PubMed was the only database searched.

In contrast to Siemens et al, ${ }^{6}$ this review comprises all outcome categories: OOMs, PROs, and GBMs. However, not all OOMs of the included studies were evaluated. Rare OOMs (eg, laxation within 24 or 48 hours) were not included and they provide information that is not addressed in this review.

It can be criticized that different populations were included in the meta-analyses. However, the heterogeneity was low except for abdominal pain. Therefore, we performed a subgroup analysis (Figure 4) and sensitivity analysis (Figure 5) only for abdominal pain and compared cancer versus noncancer patients.

The judgment of the key points was based on the effects (mostly RRs), 95\% CIs, and number of available RCTs for the different outcomes. The judgment procedure was not systematic. No officially accepted scheme has been used, for example, Grading of Recommendations Assessment, Development and Evaluation. ${ }^{46}$ However, a risk of bias assessment was performed according to Cochrane standards (Figure 8$).{ }^{31}$

Concerning the AEs meta-analyses, only the $450 \mathrm{mg}$ group from the study of Rauck et $\mathrm{al}^{37,41}$ was used but not the 150 and $300 \mathrm{mg}$ groups (Figures 3-7). The lower dose groups tended to have fewer AEs and, thus, our choice represents a conservative approach. In the RCT from Slatkin et al, ${ }^{39}$ the results for an RFBM within 4 hours hardly differed between both MNTX groups (61.7\% vs 58.2\% for MNTX 0.15 and $0.3 \mathrm{mg} / \mathrm{kg}$, respectively). Therefore, these groups were combined for the meta-analysis in Figure 2.

We decided not to perform meta-analysis for the outcome groups BM frequency and time to laxation. These outcomes were assessed in three (43\%) and five (71\%) of the seven included studies, respectively. However, the outcomes and the quality of data were heterogeneous and prohibited reasonable meta-analysis.

\section{Conclusion}

The evaluation of MNTX for OIC treatment is often based on OOMs and less often on PROs and GBMs. MNTX has been shown to be effective for most outcomes assessed in the included RCTs. However, no or only a weak dose-response relationship can be assumed based on the data of the investigated doses. MNTX can be regarded as comparatively safe because hardly any SAEs can be attributed to the drug.
However, there is a considerable risk for an increase in abdominal pain, probably related to the intended prokinetic effects of MNTX.

Future RCTs could research the efficacy of MNTX in other populations, for example, in patients under opioids after surgical procedures. Moreover, PROs and GBMs should be an integral part of the efficacy evaluation in order to consider the patients' perspective of improvement or deterioration of OIC.

\section{Acknowledgments}

We are very grateful to Mayang Mayang, graduate assistant at the Department of Palliative Care, University Medical Center Freiburg, for her help with data extraction and proofreading. The review was not funded.

\section{Author contributions}

WS wrote the article, conducted the meta-analyses, finalized, and approved the draft. GB contributed to the manuscript, critically revised it for methodological and medical issues, and approved the final version. All authors contributed toward data analysis, drafting and critically revising the paper and agree to be accountable for all aspects of the work.

\section{Disclosure}

The authors report no conflicts of interest in this work.

\section{References}

1. Brock C, Olesen SS, Olesen AE, Frøkjaer JB, Andresen T, Drewes AM. Opioid-induced bowel dysfunction: pathophysiology and management. Drugs. 2012;72(14):1847-1865.

2. Bader S, Jaroslawski K, Blum HE, Becker G. Opioid-induced constipation in advanced illness: safety and efficacy of methylnaltrexone bromide. Clin Med Insights Oncol. 2011;5:201-211.

3. Bell TJ, Panchal SJ, Miaskowski C, Bolge SC, Milanova T, Williamson R. The prevalence, severity, and impact of opioid-induced bowel dysfunction: results of a US and European Patient Survey (PROBE 1). Pain Med. 2009; 10(1):35-42.

4. Panchal SJ, Müller-Schwefe P, Wurzelmann JI. Opioid-induced bowel dysfunction: prevalence, pathophysiology and burden. Int J Clin Pract. 2007;61(7):1181-1187.

5. Meuser T, Pietruck C, Radbruch L, Stute P, Lehmann KA, Grond S. Symptoms during cancer pain treatment following WHO-guidelines: a longitudinal follow-up study of symptom prevalence, severity and etiology. Pain. 2001;93(3):247-257.

6. Siemens W, Gaertner J, Becker G. Advances in pharmacotherapy for opioid-induced constipation - a systematic review. Expert Opin Pharmacother. 2015;16(4):515-532.

7. Poulsen JL, Brock C, Olesen AE, Nilsson M, Drewes AM. Clinical potential of naloxegol in the management of opioid-induced bowel dysfunction. Clin Exp Gastroenterol. 2014;7:345-358.

8. Becker G, Blum HE. Novel opioid antagonists for opioid-induced bowel dysfunction and postoperative ileus. Lancet. 2009;373(9670): $1198-1206$. 
9. Coyne K, LoCasale R, Datto C, Sexton C, Yeomans K, Tack J. Opioidinduced constipation in patients with chronic noncancer pain in the USA, Canada, Germany, and the UK: descriptive analysis of baseline patient-reported outcomes and retrospective chart review. Clinicoecon Outcomes Res. 2014;24(6):269-281.

10. Hjalte F, Berggren A, Bergendahl H, Hjortsberg C. The direct and indirect costs of opioid-induced constipation. J Pain Symptom Manage. 2010;40(5):696-703.

11. Leppert W. Emerging therapies for patients with symptoms of opioid-induced bowel dysfunction. Drug Des Devel Ther. 2015;9: 2215-2231.

12. Ford AC, Brenner DM, Schoenfeld PS. Efficacy of pharmacological therapies for the treatment of opioid-induced constipation: systematic review and meta-analysis. Am J Gastroenterol. 2013;108(10):1566-1574.

13. European Medicines Agency. Available from: http://www.ema.europa. eu/ema/index.jsp?curl=pages $/$ medicines $/$ human $/$ medicines $/ 000870 /$ human_med_001022.jsp\&mid=WC0b01ac058001d124. Accessed October 28, 2015.

14. Holzer P. Opioids and opioid receptors in the enteric nervous system: from a problem in opioid analgesia to a possible new prokinetic therapy in humans. Neurosci Lett. 2004;361(1-3):192-195.

15. Kumar L, Barker C, Emmanuel A. Opioid-induced constipation: pathophysiology, clinical consequences, and management. Gastroenterol Res Pract. 2014;2014:141737.

16. Benyamin R, Trescot AM, Datta S, et al. Opioid complications and side effects. Pain Physician. 2008;11(2 Suppl):S105-S120.

17. Gaertner J, Siemens W, Camilleri M, et al. Definitions and outcome measures of clinical trials regarding opioid-induced constipation: a systematic review. J Clin Gastroenterol. 2015;49(1):9-16.

18. Longstreth GF, Thompson WG, Chey WD, Houghton LA, Mearin F, Spiller RC. Functional bowel disorders. Gastroenterology. 2006;130(5): 1480-1491.

19. Joswick T, Mareya SM, Lichtlen P, Woldegeorgis F, Ueno R. Time to onset of lubiprostone treatment effect in chronic non-cancer pain patients with opioid-induced constipation: Data from two phase 3, randomized, double-blind, placebo-controlled trials. Gastroenterology. 2013;144(5 Supplement 1):540.

20. Lichtlen P, Joswick T, Woldegeorgis F, Ueno R. Lubiprostone is well tolerated in chronic non-cancer pain patients with opioid-induced constipation in three phase 3, randomized, double-blind, placebocontrolled trials. Gastroenterology. 2013;144(5 Supplement 1):916.

21. Mareya SM, Lichtlen P, Woldegeorgis F, Joswick T, Ueno R. Lubiprostone improves complete spontaneous bowel movement frequency in chronic non-cancer pain patients with opioid-induced constipation. Gastroenterology. 2013;144(5 Supplement 1):539-540.

22. Wirz S, Nadstawek J, Elsen C, Junker U, Wartenberg HC. Laxative management in ambulatory cancer patients on opioid therapy: a prospective, open-label investigation of polyethylene glycol, sodium picosulphate and lactulose. Eur J Cancer Care (Engl). 2012;21(1): 131-140.

23. Irving G, Penzes J, Ramjattan B, et al. A randomized, placebo-controlled phase 3 trial (Study SB-767905/013) of alvimopan for opioidinduced bowel dysfunction in patients with non-cancer pain. J Pain. 2011;12(2):175-184.

24. Jansen JP, Lorch D, Langan J, et al. A randomized, placebo-controlled phase 3 trial (Study SB-767905/012) of alvimopan for opioidinduced bowel dysfunction in patients with non-cancer pain. J Pain. 2011;12(2):185-193

25. Wirz S, Wittmann M, Schenk M, et al. Gastrointestinal symptoms under opioid therapy: a prospective comparison of oral sustained-release hydromorphone, transdermal fentanyl, and transdermal buprenorphine. Eur J Pain. 2009;13(7):737-743.

26. Portenoy RK, Thomas J, Moehl BML, et al. Subcutaneous methylnaltrexone for the treatment of opioid-induced constipation in patients with advanced illness: a double-blind, randomized, parallel group, dose-ranging study. J Pain Symptom Manage. 2008;35(5):458-468
27. Wirz S, Wartenberg HC, Nadstawek J. Less nausea, emesis, and constipation comparing hydromorphone and morphine? A prospective open-labeled investigation on cancer pain. Support Care Cancer. 2008; 16(9):999-1009.

28. Prichard D, Bharucha A. Management of opioid-induced constipation for people in palliative care. Int J Palliat Nurs. 2015;21(6):272-280.

29. Bader S, Dürk T, Becker G. Methylnaltrexone for the treatment of opioid-induced constipation. Expert Rev Gastroenterol Hepatol. 2013; 7(1):13-26.

30. U.S. Food and Drug Administration. FDA Approves Relistor for Opioid-Induced Constipation. Available from: http://www.fda.gov/ NewsEvents/Newsroom/PressAnnouncements/2008/ucm116885.htm. Accessed January 15, 2016.

31. Higgins JPT, Green S. Cochrane Handbook for Systematic Reviews of Interventions. Available from: http://handbook.cochrane.org/. Accessed October 28, 2013.

32. Stovold E, Beecher D, Foxlee R, Noel-Storr A. Study flow diagrams in Cochrane systematic review updates: an adapted PRISMA flow diagram. Syst Rev. 2014;3:54.

33. Nalamachu SR, Pergolizzi J, Taylor R, et al. Efficacy and tolerability of subcutaneous methylnaltrexone in patients with advanced illness and opioid-Induced constipation: a responder analysis of 2 randomized, placebo-controlled trials. Pain Pract. 2015;15(6):564-571.

34. Neefjes EC, van der Vorst MJ, Boddaert MS, et al. Clinical evaluation of the efficacy of methylnaltrexone in resolving constipation induced by different opioid subtypes combined with laboratory analysis of immunomodulatory and antiangiogenic effects of methylnaltrexone. BMC Palliat Care. 2014;13:42.

35. Viscusi ER, Barrett AC, Paterson C, Forbes WP. Efficacy and safety of methylnaltrexone for opioid-induced constipation in patients with chronic noncancer pain: a placebo crossover analysis. Reg Anesth Pain Med. 2016;41:93-98.

36. Michna E, Blonsky ER, Schulman S, et al. Subcutaneous methylnaltrexone for treatment of opioid-induced constipation in patients with chronic, nonmalignant pain: a randomized controlled study. J Pain. 2011; 12(5):554-562.

37. Rauck RL, Peppin J, Israel R, et al. Oral methylnaltrexone for the treatment of opioid-induced constipation in patients with noncancer pain. Gastroenterology. 2012:142(suppl 1):160.

38. Bull J, Wellman CV, Israel RJ, Barrett AC, Paterson C, Forbes WP. Fixeddose subcutaneous methylnaltrexone in patients with advanced illness and opioid-induced constipation: results of a randomized, placebo-controlled study and open-label extension. J Palliat Med. 2015;18(7):593-600.

39. Slatkin N, Thomas J, Lipman AG, et al. Methylnaltrexone for treatment of opioid-induced constipation in advanced illness patients. J Support Oncol. 2009;7(1):39-46.

40. Thomas J, Karver S, Cooney GA, et al. Methylnaltrexone for opioidinduced constipation in advanced illness. N Engl J Med. 2008;358(22): 2332-2343.

41. Rauck RL, Peppin J, Israel R, et al. Oral methylnaltrexone for the treatment of opioid-induced constipation in patients with chronic non-cancer pain; In: Digestive Disease Week (DDW); May 19-22, 2012; San Diego, CA. Available from: http://www.medscape.com/viewcollection/32463. Accessed October 28, 2015.

42. Anissian L, Schwartz HW, Vincent K, et al. Subcutaneous methylnaltrexone for treatment of acute opioid-induced constipation: phase 2 study in rehabilitation after orthopedic surgery. J Hosp Med. 2012;7(2):67-72.

43. Mackey AC, Green L, Greene P, Avigan M. Methylnaltrexone and gastrointestinal perforation. J Pain Symptom Manage. 2010;40(1):e1-e3.

44. Santucci G, Battista V. Methylnaltrexone for opioid-induced constipation in patients at the end of life. Int J Palliat Nurs. 2015;21(4):162-164.

45. Corsetti M, Tack J. Naloxegol: the first orally administered, peripherally acting, mu opioid receptor antagonist, approved for the treatment of opioidinduced constipation. Drugs Today (Barc). 2015;51(8):479-489.

46. Balshem H, Helfand M, Schünemann HJ, et al. Grading of recommendations assessment, development and evaluation (short GRADE). J Clin Epidemiol. 2011;64(4):401-406. 


\section{Publish your work in this journal}

Therapeutics and Clinical Risk Management is an international, peerreviewed journal of clinical therapeutics and risk management, focusing on concise rapid reporting of clinical studies in all therapeutic areas, outcomes, safety, and programs for the effective, safe, and sustained use of medicines. This journal is indexed on PubMed Central, CAS,

EMBase, Scopus and the Elsevier Bibliographic databases. The manuscript management system is completely online and includes a very quick and fair peer-review system, which is all easy to use. Visit http://www.dovepress.com/testimonials.php to read real quotes from published authors.

Submit your manuscript here: http://www.dovepress.com/therapeutics-and-clinical-risk-management-journal 